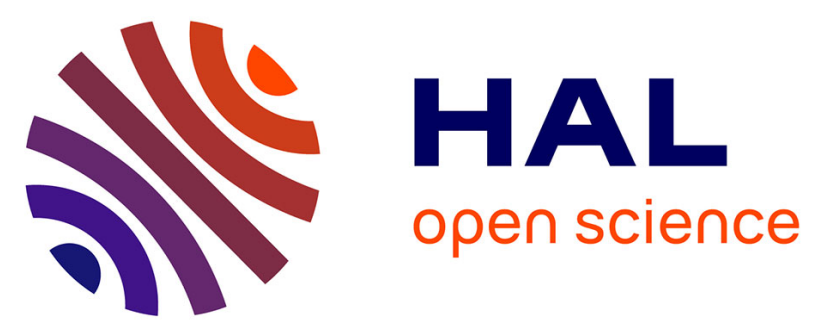

\title{
ELECTRON MICROSCOPIC OBSERVATION ON THE DISLOCATION CONFIGURATION CORRELATIVE WITH THE HIGH-TEMPERATURE INTERNAL-FRICTION PEAK IN 99.999 wt \% SINGLE-CRYSTAL ALUMINIUM
}

\author{
J. Shi, L. Zhang, T. Kê
}

\section{To cite this version:}

J. Shi, L. Zhang, T. Kê. ELECTRON MICROSCOPIC OBSERVATION ON THE DISLOCATION CONFIGURATION CORRELATIVE WITH THE HIGH-TEMPERATURE INTERNAL-FRICTION PEAK IN 99.999 wt \% SINGLE-CRYSTAL ALUMINIUM. Journal de Physique Colloques, 1985, 46 (C10), pp.C10-355-C10-358. 10.1051/jphyscol:19851079 。 jpa-00225464

\author{
HAL Id: jpa-00225464 \\ https://hal.science/jpa-00225464
}

Submitted on 1 Jan 1985

HAL is a multi-disciplinary open access archive for the deposit and dissemination of scientific research documents, whether they are published or not. The documents may come from teaching and research institutions in France or abroad, or from public or private research centers.
L'archive ouverte pluridisciplinaire HAL, est destinée au dépôt et à la diffusion de documents scientifiques de niveau recherche, publiés ou non, émanant des établissements d'enseignement et de recherche français ou étrangers, des laboratoires publics ou privés. 
JOURNAL DE PHYSIQUE

Colloque C10, supplément au $\mathrm{n}^{\circ} 12$, Tome 46 , décembre 1985 page $\mathrm{Cl0}-355$

\title{
ELECTRON MICROSCOPIC OBSERVATION ON THE DISLOCATION CONFIGURATION CORRELATIVE WITH THE HIGH-TEMPERATURE INTERNAL-FRICTION PEAK IN 99.999 wt $\%$ SINGLE-CRYSTAL ALUMINIUM
}

\author{
J. SHI, L.D. ZHANG AND T.S. KÊ \\ Institute of Solid State Physics, Academia Sinica, Hefei. \\ China
}

\begin{abstract}
The dislocation structure in sheet specimens of 99.999 wt \% aluminium single crystals was observed by transmission electron microscope (TEM) in order to explore the micromechanism corresponding to the appearance and disappearance of the internal-friction peak around $365^{\circ} \mathrm{C}(f=1 \mathrm{~Hz}) . / 1 /$ Internal-friction measurements were made with an inverted torsion pendulum on sheet specimens having a thickness of $1 \mathrm{~mm}$ or smaller and a width of $4.5 \mathrm{~mm}$. The same specimen was thinned down after'the internal-friction measurements by chemical polishing and a double jet electrolytic polishing to films about $700 \mathrm{~nm}$ thick for TEM observations. The results of internal-friction measurements were compared with TEM observations.
\end{abstract}

I. Introduction - An internal-friction peak situated at $365^{\circ} \mathrm{C}$ ( $f=1$ $\mathrm{Hz})$ was recently observed by $\mathrm{K} \hat{e}$ et al. in $99.999 \%$ aluminium single crystals. Subsequent experiments $/ 2 /$ showed that this peak appears only when the single-crystal specimen was prepared by dynamic strainannealing method and annealed subsequently at a temperature above $550^{\circ} \mathrm{C}$. Furthermore, this peak was reduced or suppressed when the single-crystal specimen was deformed at room temperature or under creep conditions. Meanwhile, the internal friction background beyond the temperature of the $365^{\circ} \mathrm{C}$ peak was considerably increased. In order to correlate the change of dislocation configuration in the specimen with the appearance and disappearance of the $365^{\circ} \mathrm{C}$ peak, TEM observations were made on the same specimen after the internal friction measurements.

II. Experimental Procedure - An aliuminium sheet $(99.999 \%)$ of $120 \mathrm{X}$ $4.5 \bar{x} 1 \mathrm{~mm}^{3}$ was annealed at $500^{\circ} \mathrm{C}$ for $0.5 \mathrm{~h}$ and then stretched at room temperature to $2.3 \%$ elongation. This sheet was put inside a tube furnace with a predetermined temperature gradient along the tube. The hottest part of the specimen was kept at a temperature of about $550^{\circ} \mathrm{C}$. The sheet was displaced in the furnace with a uniform speed of 2.5 $\mathrm{cm} / \mathrm{h}$. The single crystal specimen thus prepared was mounted in an 
inverted torsion pendulum for internal friction measurements. After the measurements, the specimen was cut to several portions and thinned down by chemical polishing to $0.1 \mathrm{~mm}$ by soaking in a solution of $\mathrm{NaOH}$ $(20 \mathrm{~g})$ and $\mathrm{H}_{2} \mathrm{O}(100 \mathrm{ml})$ at $70^{\circ} \mathrm{C}$. It was then treated by a double jet electrolytic polishing to films about $700 \mathrm{~nm}$ for TEM observations in a high resolution electron microscope (TEM-200 cx) at a working voltage of $200 \mathrm{kV}$.

\section{Experimentail Results -}

III. 1. A single-crystal specimen (containing about 2--3 bamboo boundaries along a length of $120 \mathrm{~mm}$ ) of $1 \mathrm{~mm}$ thick was mounted in an inverted torsion pendulum, and internal friction measurements were taken with ascending temperatures. The internal friction curve thus obtained is shown by curve 1 of Fig. 1. It is seen that the internal friction increases monotonously with temperature and a small plateau appeared around $410^{\circ} \mathrm{C}$. This specimen was annealed at $600^{\circ} \mathrm{C}$ for $2 \mathrm{~h}$ and internal-friction measurements started at $550^{\circ} \mathrm{C}$ in descending temperatures with a speed of $2^{\circ} \mathrm{C} / \mathrm{min}$. An internal friction peak appeared pronouncediy at $410^{\circ} \mathrm{C}(f=1.7 \mathrm{~Hz}$ ) with a height of 0.02 as shown by curve 2 of Fig. 1. It can be seen that this peak is the $369^{\circ} \mathrm{C}$ peak with $f=1 \mathrm{~Hz}$.

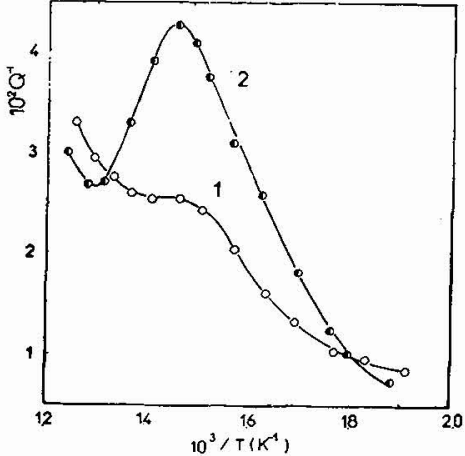

Fig. 1. Internal friction curves of 99.999 aluminium single crystal prepared by dynamic strain annealing method: Curve 1. Measured in ascending temperatures. Curve 2 . After an annealing at $600^{\circ} \mathrm{C}$ for $2 \mathrm{~h}$. $f=1.7 \mathrm{~Hz}$.

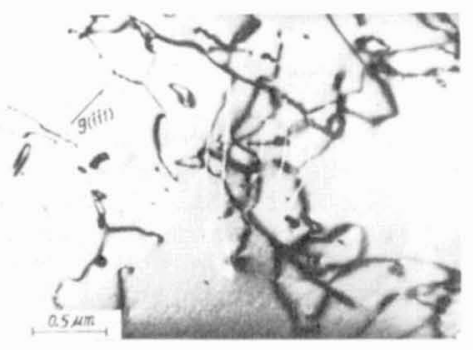

Fig. 2. Dislocation configuration in 99.999 aluminium single crystal after an annealing at $6.00^{\circ} \mathrm{C}$ for $2 \mathrm{~h}$.

The dislocations in the specimen exhibiting a $1365^{\circ} \mathrm{C}$ peak" observed by TEM in the film prepared from this specimen are dispersive (polygonization boundaries were not observed). They wove together to form a uniform spatial network with many nodes as shown in Fig. 2. Diffraction contrast analysis by tilting the film showed that the dislocations composing the spatial network are not situated on the same plane. Such a dislocation configuration is a stable structure formed by annealing at an elevated temperature above $550^{\circ} \mathrm{C}$. The dislocations forming the network are of the edge-type. Repeated measurements showed that the dislocation density is about $10^{8}$ to $10^{9} / \mathrm{cm}^{2}$. The dislocation segment. between the spatial rodes is quite long with an average length of about $0.5--1 \mathrm{um}$. Diffraction contrast analysis showed that screw dislocation does not exist.

III. 2. Another single-crystal specimen prepared by dynamic annealing method was mounted in the torsion pendulum apparatus and the internal friction curve measured with ascending temperatures is shown 
by curve 1 of Fig. 3. The internal. friction increases monotonously with temperature and a plateau appeared at a temperature region lower than that shown by curve 1 of $\mathrm{Fig.} 1$. When the temperature is raised to $450^{\circ} \mathrm{C}$ and internal friction is taken with descending temperatures a hump appeared around the region of $350--450^{\circ} \mathrm{C}$. This indicates that the $450^{\circ} \mathrm{C}$ annealing is not sufficient to have the $365^{\circ} \mathrm{C}$ peak well developed as in the case shown by curve 2 of Fig. 1 after an anneal of $600^{\circ} \mathrm{C}$.

TEM observations showed that the dislocations in the specimen film wove into a complex irregular structure as shown in Fig. 4 (a). The average distance between the nodes is much shorter as compared with that shown in Fig. 2. There is only a small proportion showing the spatial network structure af in $\mathbf{P}$. 4. (b). The dimension of the network is large and very irregular.
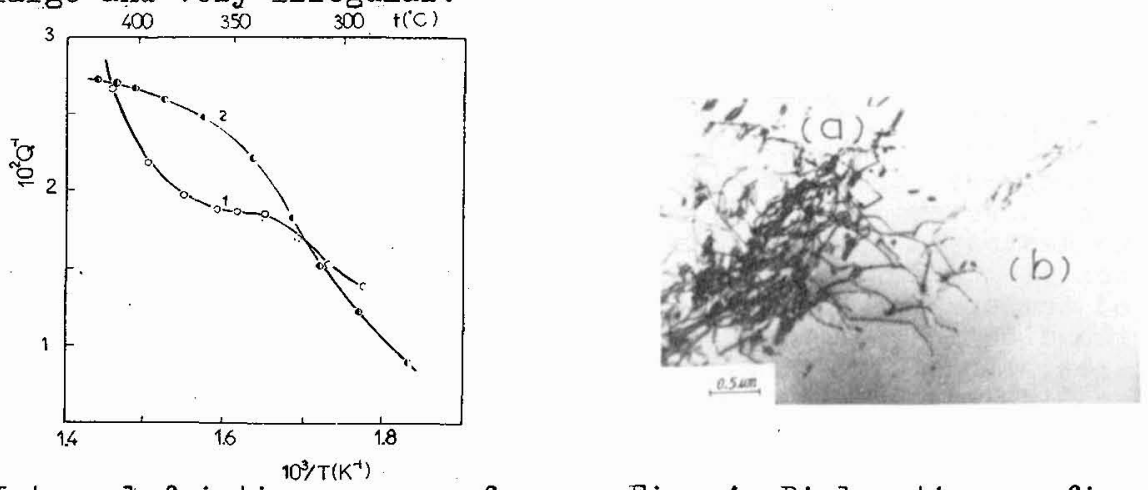

Fig. 3. Internal friction curves of 99.999 aluminium single crystal: Curve 1 . Measured in ascending temperatures. Curve 2. Measurements started at $435^{\circ} \mathrm{C}$ with descending temperatures. $f=1.8 \mathrm{~Hz}$.

Fig. 4. Dislocation configuration in 99.999 aluminium single crystal after heating up to $435^{\circ} \mathrm{C}$.

III. 3. The single-crystal specimen exhibiting the $" 365^{\circ} \mathrm{C}$ peak" was deformed $3 \%$ at room temperature and then annealed at $600^{\circ} \mathrm{C}$ for $2 \mathrm{~h}$. The internal friction was measured with descending temperatures and the $365^{\circ} \mathrm{C}$ peak disappeared as shown in Fig. 5. TEM observations on the

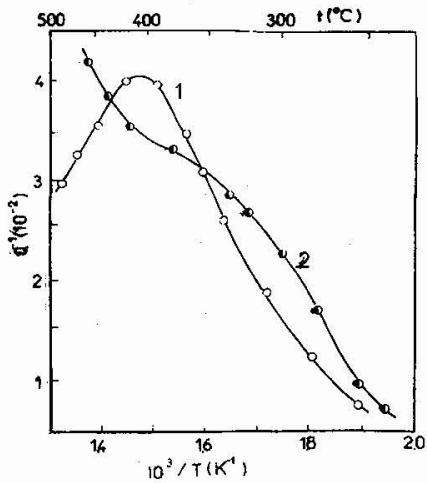

Fig. 5. Internal friction curves of 99.999 aluminium single crystal: Curve 1. Annealed at $600^{\circ} \mathrm{C}$ for $2 \mathrm{~h}$. Curve 2 . Stretched $3 \%$ at room temperature and then annealed at $600^{\circ} \mathrm{C}$ for $2 \mathrm{~h} . \mathrm{f}=1.8$ $\mathrm{Hz}$.

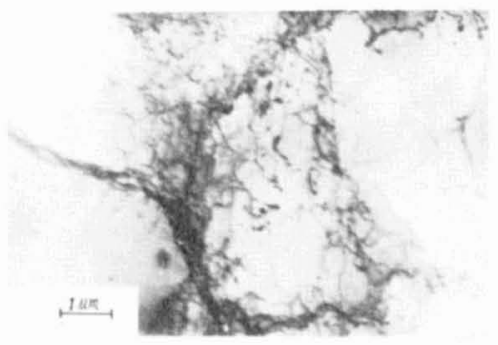

Fig. 6. Dislocation configuration in 99.999 aluminium single crystal stretched $3 \%$ at room temperature and then annealed at $600^{\circ} \mathrm{C}$ for $2 \mathrm{~h}$. 
film prepared from this specimen showed that the dislocation density increases considerably to exceed $10^{10} / \mathrm{cm}^{2}$ with the formation of cell structures having an average size of several $\mu \mathrm{m}$. as is shown in Fig. 6 . The dislocations are concentrated at the walls of the cell. The misorientation angle between the cell structures was found to be about $0.1^{\circ}$.

IV: Discussions - Conclusions can be made according to the result of internal friction measurements and TEM observations that the $1365^{\circ} \mathrm{C}$ peak" appeared in 99.999 wt o aluminium single crystal is correlated to the existence of the spatial network wove together by dispersive dislocations in three-dimensional crystal lattice. This peak is suppressed by the appearance of cell structures when the single crystal specimen was subjected to $3 \%$ stretching at room temperature.

The proportion of the spatial network and the ceil structure determine the appearance and disappearance of the $365^{\circ} \mathrm{C}$ peak and the height of the peak. The $365^{\circ} \mathrm{C}$ peak only appears after the single crystal specimen prepared by dynamic annealing method was annealed at an elevated temperature. Consequently, an annealing at an elevated temperature is a necessary condition for the formation of this stable spatial network. However, once this stable structure in a single crystal specimen was destroyed by deformation with the formation of cell structures, then it cannot be reformed again simply by an annealing at an elevated temperature. Instead, the high temperature internal friction background beyond $365^{\circ} \mathrm{C}$ increased with the existence of such cell structures. TEM diffraction contrast analysis showed that some of the dislocation segments composing the spatial network are situated on high index planes. This indicates that dislocation climb is the principal process in forming the spatial network.

\section{References}

/1/ T. S. Kê, P. Cui, and C. M. Su, phys, stat. sol. (a) 84, 157 (1984).

$/ 2 /$ C. M. Su and T. S. Kề, this Conference.

/3/ I. D. Zhang and T. S. Kê, Proc. Yamada Conference IX on Dislocations in Solids, Tokyo/Japan, August 1984. 